\title{
Assessment of contaminant levels and trophic relations at a World Heritage Site by measurements in a characteristic shorebird species
}

\author{
Philipp Schwemmer ${ }^{\mathrm{a}, *}$, Adrian Covaci ${ }^{\mathrm{b}}$, Krishna Das ${ }^{\mathrm{c}}$, Gilles Lepoint ${ }^{\mathrm{c}}$, Sven Adler ${ }^{\mathrm{d}}$, \\ Stefan Garthe ${ }^{\text {a }}$ \\ ${ }^{a}$ Research and Technology Centre (Forschungs- und Technologiezentrum), University of Kiel, Hafentörn 1, 25761 Büsum, Germany \\ ${ }^{\mathrm{b}}$ Toxicological Center, University of Antwerp, Universiteitsplein 1, 2610 Wilrijk, Belgium \\ c Laboratory for Oceanology-MARE Research Center, University of Liege, Allée de la Chimie 17, B6C, Institut de Chimie, 4000 Liege (Sart-Tilman), Belgium \\ d Swedish University of Agricultural Sciences, 90183 Umeå, Sweden
}

\section{A R T I C L E I N F O}

\section{Article history:}

Received 29 August 2014

Received in revised form

11 October 2014

Accepted 27 October 2014

\section{Keywords:}

Eurasian oystercatcher

Haematopus ostralegus

Wadden Sea

PCB

PBDE

Stable isotopes

\begin{abstract}
A B S T R A C T
The River Elbe is responsible for influxes of contaminants into the Wadden Sea World Heritage Site. We investigated levels of polychlorinated biphenyls (PCBs), oxychlordane $(\mathrm{OxC})$, hexachlorobenzene (HCB), hexachlorocyclohexanes $(\alpha-, \beta$-, $\gamma$-HCHs), dichlorodiphenyltrichloroethane (DDT) and its metabolites, and polybrominated diphenyl ethers (PBDEs) in blood and feathers from Eurasian oystercatchers (Haematopus ostralegus; $n=28$ ) at the Elbe and compared it with a non-riverine site about $90 \mathrm{~km}$ further north. (1) Mean levels of all contaminants in feathers and serum were significantly higher at the river ( $\sum$ PCBs: $27.6 \mathrm{ng} / \mathrm{g}$ feather, $37.0 \mathrm{ng} / \mathrm{ml}$ serum; $\sum$ DDTs: $5.3 \mathrm{ng} / \mathrm{g}$ feather, $4.4 \mathrm{ng} / \mathrm{ml}$ serum) compared with the non-riverine site ( $\sum$ PCBs: $6.5 \mathrm{ng} / \mathrm{g}$ feather, $1.2 \mathrm{ng} / \mathrm{ml}$ serum; $\sum$ DDTs: $1.4 \mathrm{ng} / \mathrm{g}$ feather, $0.5 \mathrm{ng} / \mathrm{ml}$ serum). Mean $\Sigma \mathrm{HCH}$ and $\mathrm{HCB}$ levels were $<1.8 \mathrm{ng} / \mathrm{g}$ in feather and $<1.8 \mathrm{ng} / \mathrm{ml}$ in serum at both sites. (2) Levels of most detectable compounds in serum and feathers were significantly related, but levels were not consistently higher in either tissue. (3) There was no significant relationship between trophic level in individual oystercatchers (expressed as $\delta 15 \mathrm{~N}$ ) or the degree of terrestrial feeding (expressed as 813C) and contaminant loads. (4) PBDEs were not detected in significant amounts at either site. The results of this study indicate that the outflow from one of Europe's largest river systems is associated with significant historical contamination, reflected by the accumulation of contaminants in body tissues in a coastal benthivore predator.
\end{abstract}

(c) Elsevier Inc. All rights reserved.

\section{Introduction}

The North Sea is one of the most intensively used marine regions in the world (Halpern et al., 2008). It receives major influxes of nutrients and contaminants from several large river systems, including the Elbe (Bakker et al., 2009). Moreover, the Wadden Sea, located in the south-eastern North Sea, was declared a World Heritage Site in 2009 (CWSS, 2008) and provides food and space for millions of breeding and resting birds. Monitoring of population trends and numbers to assess changes in the quality of this important wetland site have identified alarming negative trends

\footnotetext{
*Correspondence to: FTZ, Hafentörn 1, D-25761 Büsum, Germany. Fax: +494834604299.

E-mail addresses: schwemmer@ftz-west.uni-kiel.de (P. Schwemmer), adrian.covaci@uantwerpen.be (A. Covaci), krishna.das@ulg.ac.be (K. Das), g.lepoint@ulg.ac.be (G. Lepoint), sven.adler@slu.se (S. Adler), garthe@ftz-west.uni-kiel.de (S. Garthe).
}

(Laursen et al., 2010; Blew et al., 2013; Koffijberg et al., 2013). Birds are widely used as indicators of health of the marine environment. They are found in the upper levels of the food web and therefore provide useful evidence for the accumulation of persistent contaminants (e.g., Furness, 1993; Thompson and Hamer, 2000; Dittmann et al., 2011), as well as for important changes in trophic relations (e.g., Montevecchi, 1993; Montevecchi and Myers, 1996; Schwemmer et al., 2013).

The contaminant loads of birds inhabiting this internationally important ecosystem have been monitored in terms of persistent organic substances (i.e., polychlorinated biphenyls (PCBs), dichlorodiphenyltrichloroethanes (DDTs), hexachlorocyclohexanes (HCHs), hexachlorobenzene (HCB), chlordane) and heavy metals (i.e., mercury) since the 1980 s, and regularly since the 1990 s (Becker and Muñoz Cifuentes, 2004). The results of this monitoring have provided insights into long-term changes in contaminant loads in the eggs of piscivorous (i.e., terns) and benthivorous (i.e., oystercatchers Haematopus ostralegus) marine birds. 
High breeding and resting numbers (Laursen et al., 2010; Koffijberg et al., 2013) mean that oystercatchers are one of the most characteristic species in the Wadden Sea. Contaminants in egg shells of oystercatchers have been shown to differ between different sites on the Wadden Sea, with the outflow of the River Elbe as an important hotspot (Becker et al., 1992; Beyerbach et al., 1993; Becker and Muñoz Cifuentes, 2004; Becker and Dittmann, 2009). Although overall levels of all contaminants in most parts of the Wadden Sea (including the Elbe river area) have declined during recent years, levels remain highest in the vicinity of the Elbe outflow (Becker and Dittmann, 2009). Intertidal mudflats and salt marshes in the Elbe estuary provide important feeding and resting areas for various waterbird species, including oystercatchers (Koffijberg et al., 2003).

We investigated the relevance of different types of organic contaminants in the south-eastern Wadden Sea, with a focus on major river influxes. This study had four major objectives:

(1) We compared contaminant levels and compositions of PCBs, $\mathrm{HCB}$, oxychlordane (OxC), $\alpha-, \beta-, \gamma-\mathrm{HCHs}$, DDT and its metabolites, and polybrominated diphenyl ethers (PBDEs) between the River Elbe area and Hallig Oland, another important breeding site located about $90 \mathrm{~km}$ further north, with no riverine influence. Oystercatchers are very local during the breeding period (Schwemmer and Garthe, 2011), and individual oystercatchers thus reflect contaminant loads from their respective site.

(2) We compared contaminant patterns in blood and feathers from oystercatchers at the two sites to detect differences between different tissues (e.g., Jaspers et al., 2006; Voorspoels et al., 2006; Ahrens et al., 2009). Levels in feathers might integrate contaminant loads over a relatively long period of time and thus be influenced by contaminant levels in areas used outside the breeding period (Jaspers et al., 2007). Blood levels, however, indicate contaminant levels during the breeding period, and thus reflect contaminant loads at distinct breeding sites. We also examined the relationship between contaminant levels in feathers and those in blood, as suggested by Jaspers et al. $(2007,2008)$ for other bird species.

(3) Trophic position of consumers such as birds and the origin of prey can be investigated by analysis of stable isotopes (Inger and Bearhop, 2008). We therefore measured carbon $\left(\delta^{13} \mathrm{C}\right)$ and nitrogen $\left(\delta^{15} \mathrm{~N}\right)$ in red blood cells, serum and feathers to assess potential differences in feeding behaviours between individuals breeding at the two sites. $\delta^{13} \mathrm{C}$ in body tissues of consumers provides information on prey origins (i.e., low $\delta^{13} \mathrm{C}$ values indicate terrestrial origin, whereas high values indicate marine origin); $\delta^{15} \mathrm{~N}$ levels provide information on the trophic level of the prey (i.e., high $\delta^{15} \mathrm{~N}$ indicates prey from higher trophic levels; Fry, 2006; Inger and Bearhop, 2008; Ceia et al., 2014). We therefore aimed to relate levels of different types of pollutants to the feeding habits of the birds (Jaspers et al., 2007). We hypothesised that higher contaminant loads would be accompanied by higher $\delta^{15} \mathrm{~N}$ levels as a consequence of birds foraging at higher trophic levels, and by higher $\delta^{13} \mathrm{C}$ levels as a result of foraging in more contaminated marine environments (when foraging terrestrially, oystercatchers commonly use pastures which in our study area are not treated with agricultural contaminants).

(4) Finally, we investigated the importance of PBDE contamination in birds in the Wadden Sea, particularly at the River Elbe site. PBDEs have been less-well investigated than many other substances, but have been suggested to influence hormone levels in different organisms (WWF, 2000; Jaspers et al., 2006; Voorspoels et al., 2006).

\section{Methods}

\subsection{Study area}

Incubating adult oystercatchers $(n=28)$ were caught in the saltmarsh of Kaiser Wilhelm Koog (535 $57^{\prime} 55$ N, $8^{\circ} 54^{\prime} 14 \mathrm{E} ; n=11$ ) and on pastures on Hallig Oland ( $54^{\circ} 41^{\prime} 52 \mathrm{~N}, 8^{\circ} 42^{\prime} 18 \mathrm{E} ; n=17$ ) in summer 2008 using walk-in nest traps (Fig. 1). The first site was located in the immediate vicinity of the River Elbe outflow, which is a significant source of contaminants (Bakker et al., 2009), while the latter site was located on an island in the north-eastern Wadden Sea, with no major river inflows. Both study areas are about $90 \mathrm{~km}$ apart. As oystercatchers show very local foraging flights (maximum up to $4 \mathrm{~km}$ distance) during the breeding period (Schwemmer and Garthe 2011) we can exclude that oystercatchers switched between the two study sites.

\subsection{Sampling}

Caught birds were ringed and about $1 \mathrm{ml}$ of blood was taken from the brachial vein and preserved in serum tubes. Bird-catching and blood-sampling procedures complied with EC Directive 86/ 609/EEC for animal experiments and current German laws. Permits were obtained from the Ministerium für Landwirtschaft Umwelt und ländliche Räume (file numbers V 312-72241.121-37 (69-6/07) and V 312-72241.121-37 (27-3/08)). Samples were

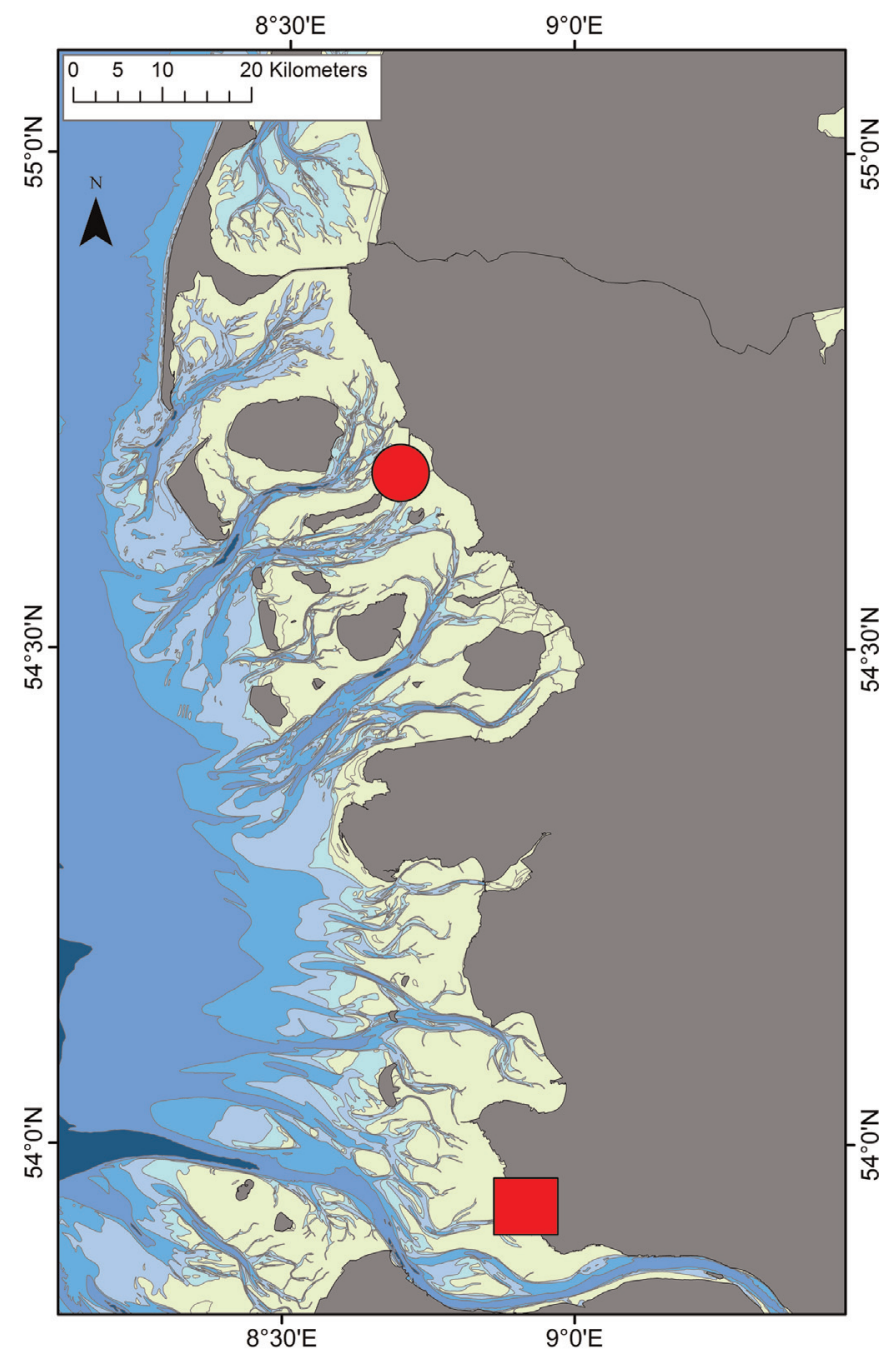

Fig. 1. German North Sea coast indicating sampling locations on the River Elbe (square) and Hallig Oland (circle). 
centrifuged immediately to separate serum from red blood cells. One feather was cut from the wing coverts (outermost wing coverts) using scissors. All samples were stored at $-20^{\circ} \mathrm{C}$ until analysis. It was not possible to extract sufficient blood from all the caught birds, and blood samples were only obtained from eight birds from Oland, but all 11 birds from the Elbe River. Feather samples were taken from 16 birds from Oland, and from all 11 birds from the Elbe River. No feather was taken from one Oland bird, and no $\delta^{15} \mathrm{~N}$ value could be determined in a further Oland bird.

\subsection{Analyses of pollutants}

Fifteen PCB congeners were analysed in feathers (i.e. 28, 52, 99, $101,105,118,128,138,146,149,153,170,180,183$ and 187). The same congeners (except CB 28 and 52) were analysed in serum, together with congener 156 . HCB, OxC, trans-nonachlor (TN), cisnonachlor (CN), $\alpha-, \beta-, \gamma$-HCHs and $p, p^{\prime}$-DDT and its metabolites $p$, $p^{\prime}$-DDE and $p, p^{\prime}$-DDD, (expressed as sum $(\Sigma)$ DDTs) were analysed in all samples (apart from $p, p^{\prime}$-DDD, which was not analysed in serum). Finally, eight PBDE congeners (i.e. 28, 47, 49, 99, 100, 153, 154, and 183) and 2-MeO-BDE68 and 6-MeO-BDE47 were analysed in both tissues.

The concentrations of contaminants in body feathers and serum were analysed at the Toxicological Centre (University of Antwerp, Belgium), as described previously (Eulaers et al., 2011). Briefly, individual feathers were rinsed thoroughly with distilled water and dried overnight at ambient temperature. After cutting into approximately $1 \mathrm{~mm}$ pieces, feather samples were weighed and spiked with internal standards (10 ng CB 143, 1 ng BDE 77, and $2 \mathrm{ng} \varepsilon-\mathrm{HCH})$. Analytes were incubated overnight at $45^{\circ} \mathrm{C}$ in $8 \mathrm{~mL}$ of $\mathrm{HCl}(4 \mathrm{M})$ and $8 \mathrm{~mL}$ of hexane:dichloromethane (4:1, v:v), and then liquid/liquid extracted using $10 \mathrm{~mL}$ hexane:dichloromethane $(4: 1, \mathrm{v}: \mathrm{v})$. The extracts were cleaned on acidified silica ( $800 \mathrm{mg}$; $44 \% \mathrm{H}_{2} \mathrm{SO}_{4}$ ) topped with anhydrous $\mathrm{Na}_{2} \mathrm{SO}_{4}(400 \mathrm{mg}$ ), and eluted with $8 \mathrm{~mL}$ of hexane:dichloromethane $(1: 1 \mathrm{v}: \mathrm{v})$. Cleaned extracts were further evaporated to dryness and reconstituted in $100 \mu \mathrm{L}$ iso-octane.

Serum samples were spiked with internal standards (10 ng CB 143, 1 ng BDE 77, and 2 ng $\varepsilon-\mathrm{HCH}$ ), diluted 1:1 with Milli Q water, mixed with formic acid, sonicated for 20 min and extracted using solid-phase extraction cartridges ( $3 \mathrm{~mL} / 60 \mathrm{mg}$ Oasis HLB, Waters). After elution with $5 \mathrm{~mL}$ dichloromethane, the extracts were cleaned on $500 \mathrm{mg}$ acidified silica. Analytes were eluted with $8 \mathrm{~mL}$ hexane:dichloromethane $(1: 1, \mathrm{v}: \mathrm{v})$, evaporated to near dryness, and reconstituted in $100 \mu \mathrm{L}$ iso-octane.

PBDEs, MeO-PBDEs, HCHs and chlordanes were analysed using a gas chromatography-mass spectrometer (GC-MS) operated in electron capture negative ionisation mode, equipped with a $30 \mathrm{~m} \times 0.25 \mathrm{~mm} \times 0.25 \mu \mathrm{m}$ DB-5 capillary column (J\&W Scientific). The ion-source temperature was $170{ }^{\circ} \mathrm{C}$. The MS was used in the SIM mode with two ions monitored for each compound in specific windows, while ions $m / z=79$ and 81 were monitored for MeOPBDEs and PBDEs during the entire run. Two microlitres of the extract were injected in cold pulsed splitless mode, splitless time $1.50 \mathrm{~min}$. Helium was used at constant flow $(1.0 \mathrm{~mL} / \mathrm{min})$.

PCBs, HCB and DDTs ( $p, p^{\prime}$-DDT, $p, p^{\prime}$-DDE and $p, p^{\prime}$-DDD) were analysed by GC-MS in electron impact ionisation mode, equipped with a $25 \mathrm{~m} \times 0.22 \mathrm{~mm} \times 0.25 \mu \mathrm{m}$ HT-8 capillary column (SGE). The ion-source temperature was $230^{\circ} \mathrm{C}$. The MS was used in SIM mode with two ions monitored for each $\mathrm{PCB}$ homologue group or compound in specific windows. Two microlitres of the extract were injected in cold pulsed splitless mode, splitless time $1.50 \mathrm{~min}$. Helium was used at constant flow $(1.0 \mathrm{~mL} / \mathrm{min})$.

Multi-level calibration curves $\left(r^{2}>0.999\right)$ in the linear response interval of the detector were created for quantification.
Quality control was performed by regular analyses of procedural blanks and random injection of standards, spiked samples and solvent blanks. The quality control scheme was also assessed by regular participation in inter-laboratory comparison exercises organised by the Arctic Monitoring and Assessment Programme (persistent organic pollutants in serum), with obtained values deviating by no more than $20 \%$ from the consensus values. The mean recoveries \pm standard deviation (SD) of the internal standards CB 143, BDE 77 and $\varepsilon$-HCH were $87 \pm 8 \%, 92 \pm 5 \%$ and $84 \pm 8 \%$, respectively. For analytes detected in the procedural blanks, the mean procedural blank value was subtracted from the result. After blank subtraction, the limit of quantification (LOQ) was set at three times the SD of the procedural blank. For analytes that were not detected in procedural blanks, LOQs were calculated for $S / N=10$. LOQs for the analysed contaminants are given in Table 1.

\subsection{Analyses of stable isotopes}

Freeze-dried blood cells, serum and feathers (tips of feathers were used to avoid variability; see Bontempo et al., 2014) were ground to a powder using a mortar and pestle and loaded into tin boats. All feathers analysed were black. The high melanin content of black feathers leads to a depletion en $13 \mathrm{C}$ and 15N (Michalik et al. 2010). However, as all feathers showed similar pigment levels the depletion was consistent over all samples. Stable isotope measurements were performed using an isotope ratio mass spectrometer (V.G. Optima, Micromass) coupled to an N-C-S elemental analyser (Carlo Erba) for automated analyses. Stable isotope abundances are expressed in delta $(\delta)$ notation as the deviation from standards in parts per thousand (\%o), according to the following equation:

$\delta \mathrm{X}=\left[\frac{R_{\text {sample }}-R_{\text {standard }}}{R_{\text {standard }}}\right] \times 1000$

where $\mathrm{X}$ is ${ }^{13} \mathrm{C}$ or ${ }^{15} \mathrm{~N}$ and $R$ is the corresponding ratio ${ }^{13} \mathrm{C} /{ }^{12} \mathrm{C}$ or ${ }^{15} \mathrm{~N} /{ }^{14} \mathrm{~N}$.

Standard values were based on the Vienna Pee Dee Belemnite (v-PDB) for $\delta^{13} \mathrm{C}$ measurements and atmospheric nitrogen for $\delta^{15} \mathrm{~N}$ measurements. Reference materials were IAEA-N1 $\left(\delta^{15} \mathrm{~N}=\right.$ $0.4 \pm 0.2 \%$ ) and IAEA CH- 6 (sucrose) $\left(\delta^{13} \mathrm{C}=-10.4 \pm 0.2 \%\right.$ ). Internal standards (glycine) were inserted into all runs at regular intervals to calibrate the system and to assess drift over time. SDs of internal standard replicates were $0.1 \%$ and $0.3 \%$ for carbon and nitrogen, respectively.

\subsection{Statistical analyses}

All statistical analyses were performed using the open source software package R version 3.02 (RDevelopment Core Team, 2013). Samples with levels below LOQ were assigned a value of $f \times$ LOQ with $f$ as the proportion of measurements with levels above the LOQ or the detection frequency (Voorspoels et al., 2002). The same compounds were tested in feathers and serum, except for PCBs 28 and 52, which were only tested in feathers, and PCB 156 and $p^{\prime} p$ DDD, which were only tested in serum. Compounds for which $>50 \%$ of the measurements were $<$ LOQ for a given location or tissue were excluded from statistical analyses. The following substances were therefore excluded from analysis in feathers: PCBs 28, 52, 99, 101, 105 (Oland only), 128 (Oland only), 146, 149, 183 (Oland only); OxC; TN; $\mathrm{CN} ; \gamma-\mathrm{HCH}$; and all PBDE congeners. The following substances were excluded from analysis in serum: PCB 101 (Oland only); OxC (Oland only); TN; CN; p'p-DDT; $p^{\prime} p$ DDD (Oland only); $\alpha-\mathrm{HCH} ; \gamma$-HCH; PBDEs 28, 47 (Oland only), 49, 99 (Oland only), 153, 154, 183; 2-MeO-BDE68; and 6-MeO-BDE47. 
Table 1

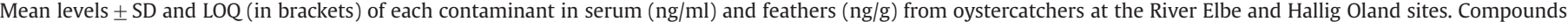
with levels < LOQ in all cases (i.e. serum, feathers, Elbe and Oland) are not shown.

\begin{tabular}{|c|c|c|c|c|}
\hline & \multicolumn{2}{|l|}{ River Elbe } & \multicolumn{2}{|l|}{ Oland } \\
\hline & Serum & Feathers & Serum & Feathers \\
\hline РСВ 99 & $1.46 \pm 0.39(0.1)$ & nd $(0.8)$ & $0.38 \pm 0.13(0.1)$ & nd $(0.8)$ \\
\hline РCB 101 & $0.14 \pm 0.08(0.1)$ & nd $(0.8)$ & nd $(0.1)$ & nd $(0.8)$ \\
\hline PCB 105 & $0.37 \pm(0.1)$ & $0.51 \pm 0.30(0.4)$ & $0.16 \pm 0.06(0.1)$ & $0.05 \pm 0.11(0.4)$ \\
\hline РCB 118 & $1.57 \pm(0.1)$ & $1.84 \pm 1.17(0.4)$ & $0.6 \pm 0.25(0.1)$ & $0.70 \pm 0.27(0.4)$ \\
\hline PCB 128 & $0.87 \pm(0.05)$ & $0.89 \pm 0.72(0.4)$ & $0.29 \pm 0.11(0.05)$ & $0.06 \pm 0.15(0.4)$ \\
\hline РCB 138 & $5.92 \pm 2(0.05)$ & $5.19 \pm 3.78(0.4)$ & $2.01 \pm 0.75(0.05)$ & $1.52 \pm 0.85(0.4)$ \\
\hline PCB 146 & $2.90 \pm 0.96(0.1)$ & nd $(0.8)$ & $0.94 \pm 0.39(0.1)$ & nd $(0.8)$ \\
\hline РСВ 149 & $0.85 \pm 0.28(0.1)$ & nd $(0.8)$ & $0.18 \pm 0.05(0.1)$ & nd $(0.8)$ \\
\hline РCB 153 & $12.29 \pm 4.37(0.05)$ & $9.99 \pm 9.55(0.4)$ & $4.02 \pm 1.85(0.05)$ & $2.30 \pm 1.38(0.4)$ \\
\hline РCB 156 & $0.44 \pm 0.16(0.05)$ & not tested & $0.17 \pm 0.09(0.05)$ & not tested \\
\hline РCB 170 & $1.70 \pm 0.74(0.05)$ & $1.71 \pm 1.26(0.4)$ & $0.60 \pm 0.30(0.05)$ & $0.47 \pm 0.25(0.4)$ \\
\hline PCB 180 & $3.92 \pm 1.63(0.05)$ & $3.71 \pm 3.28(0.4)$ & $1.07 \pm 0.60(0.05)$ & $0.85 \pm 0.42(0.4)$ \\
\hline РCB 183 & $0.82 \pm 0.36(0.05)$ & $0.75 \pm 0.62(0.4)$ & $0.29 \pm 0.139(0.05)$ & $0.06 \pm 0.14(0.4)$ \\
\hline PCB 187 & $3.71 \pm 1.30(0.05)$ & $2.98 \pm 2.72(0.4)$ & $1.28 \pm 0.52(0.05)$ & $0.68 \pm 0.44(0.4)$ \\
\hline $\mathrm{HCB}$ & $0.45 \pm 0.11(0.05)$ & $1.03 \pm 0.63(0.3)$ & $0.05 \pm 0.04(0.05)$ & $0.50 \pm 0.36(0.3)$ \\
\hline $\mathrm{OxC}$ & $0.02 \pm 0.01(0.02)$ & nd $(0.3)$ & $0.02 \pm 0.02(0.02)$ & nd $(0.3)$ \\
\hline $\mathrm{TN}$ & nd $(0.02)$ & nd $(0.2)$ & $0.02 \pm 0.01(0.02)$ & nd $(0.2)$ \\
\hline pp-DDE & $4.12 \pm 1.15(0.1)$ & $4.85 \pm 2.63(0.4)$ & $0.47 \pm 0.19(0.1)$ & $0.99 \pm 0.48(0.4)$ \\
\hline pp-DDT & nd $(0.1)$ & $0.46 \pm 0.18(0.3)$ & nd $(0.1)$ & $0.39 \pm 0.24(0.3)$ \\
\hline pp-DDD & $0.28 \pm 0.09(0.1)$ & not tested & $0.05 \pm 0(0.1)$ & not tested \\
\hline$\alpha-\mathrm{HCH}$ & nd $(0.02)$ & $0.29 \pm 0.05(0.2)$ & nd $(0.02)$ & $0.29 \pm 0.11(0.2)$ \\
\hline$\beta-\mathrm{HCH}$ & $0.71 \pm 0.26(0.02)$ & $1.58 \pm 0.85(0.2)$ & $0.11 \pm 0.04(0.02)$ & $0.47 \pm 0.19(0.2)$ \\
\hline$\gamma-\mathrm{HCH}$ & nd $(0.02)$ & nd $(0.2)$ & $0.01 \pm 0.01(0.02)$ & nd $(0.2)$ \\
\hline BDE 47 & $0.02 \pm 0.00(0.01)$ & nd $(0.1)$ & $0.01 \pm 0.01(0.01)$ & $0.05 \pm 0.19(0.1)$ \\
\hline BDE 99 & $0.01 \pm 0.01(0.01)$ & nd $(0.1)$ & $0.01 \pm 0.01(0.01)$ & $0.07 \pm 0.27(0.1)$ \\
\hline BDE 100 & $0.03 \pm 0.01(0.01)$ & $0.10 \pm 0.10(0.1)$ & $0.02 \pm 0.01(0.01)$ & $0.02 \pm 0.05(0.1)$ \\
\hline BDE 153 & nd $(0.01)$ & nd $(0.2)$ & $0.01 \pm 0.01(0.01)$ & $0.06 \pm 0.07(0.2)$ \\
\hline BDE 154 & nd $(0.01)$ & nd $(0.2)$ & $0.01 \pm 0.00(0.01)$ & nd $(0.2)$ \\
\hline
\end{tabular}

nd - not detectable.

When comparing $\sum$ PCBs, $\sum$ HCHs, HCB, $\sum$ PBDEs and $\sum$ DDTs between tissues or locations, only compounds that were found in $>50 \%$ of individuals in terms of either tissue or location, respectively, were included; i.e., if a compound was present in $<50 \%$ of tissue samples or $<50 \%$ of birds from one location, that compound was excluded from the analysis for the other tissue or location. Thus, only compounds for which tissue or location measurements were possible or where it was possible to insert a value using the formula given above were analysed.

Profiles of $\mathrm{PCB}$ congeners were analysed by computing the relative contribution of each congener to the sum of all PCBs. $\Sigma$ PCBs, $\Sigma \mathrm{HCH}$, HCB and $\Sigma$ DDTs were compared between the two sampling locations using Student's t-tests, after checking the homogeneity of variances (Sokal and Rohlf, 1981). Differences in the composition of different compounds and congeners in each tissue were detected by performing detrended correspondence analyses, including a permutation test with 1,000 permutations (DECORANA; Hill and Gauch, 1980; Oksanen and Minchin, 1997).

Relationships between contaminant levels in feathers and serum were examined. Because we detected significant differences in both levels and composition of contaminants between sites, we used linear mixed effect models with site as a random factor (Venables and Ripley, 2002; Faraway, 2006). Tests were conducted using library lme4 (Bates and Maechler, 2009). We determined if the test compound accumulated more in feathers (slope $>1$ ) or in serum (slope $<1$ ) by computing confidence intervals. Confidence intervals including the slope 1 indicated that differences in accumulation were non-significant. To test for relationships between $\sum$ PCBs, $\sum$ HCHs, HCB, $\sum$ PBDEs, $\sum$ DDTs and $\delta^{13} \mathrm{C}$ and $\delta^{15} \mathrm{~N}$, we adopted the same approach used to compare levels of contaminants between tissues, except that no confidence intervals were computed because we were only interested in regressions between contaminants and isotope profiles. $\delta^{13} \mathrm{C}$ and $\delta^{15} \mathrm{~N}$ values in different tissues were analysed by computing mean values and 25\% and 95\% percentiles for each tissue and site separately. Isotopic enrichment between diet and consumer tissues is a consequence of isotopic fractionation during the assimilation process (Ponsard and Averbuch, 1999). No fractionation factors for $\delta^{13} \mathrm{C}$ and for $\delta^{15} \mathrm{~N}$ are currently available for oystercatchers and we therefore used the values given for dunlin (Calidris alpina) whole blood, i.e., 1.3 for $\delta^{13} \mathrm{C}$ and 2.9 for $\delta^{15} \mathrm{~N}$ (Evans Ogden et al., 2004). To the best of our knowledge, these are the only available values for shorebirds.

All values were $\log$-transformed $(\log 10(x+1))$ to match a normal distribution and to allow for parametric tests.

\section{Results}

\subsection{Differences in contaminant levels and composition between locations and tissues}

Oystercatchers in both locations showed comparably high levels of PCBs in feathers and blood, respectively, whereas contamination with PBDEs was very low in both areas and tissues (Table 1; Fig. 2). Among all the tested substances, PCB 153 showed by far the highest values, both in blood $(4.02 \pm 1.85 \mathrm{ng} / \mathrm{ml}$ (Oland); $12.29 \pm 4.37 \mathrm{ng} / \mathrm{ml}$ (Elbe)) and feathers $(2.3 \pm 1.38 \mathrm{ng} / \mathrm{g}$ (Oland); $9.99 \pm 9.55 \mathrm{ng} / \mathrm{g}$ (Elbe) (Table 1 ). However, as indicated by the large SDs, PCB contamination varied considerably between individuals, particularly at the Elbe site (Table 1). Most PBDE congeners in serum were only slightly above or $<$ LOQ. PBDEs in feathers from the riverine site were $<$ LOQ in most cases, but slightly higher in feathers from the non-riverine location. Only BDE 100 was detectable in levels significantly above LOQ in serum in both locations (Fig. 2e). PBDE values were 100-1000 times 
a

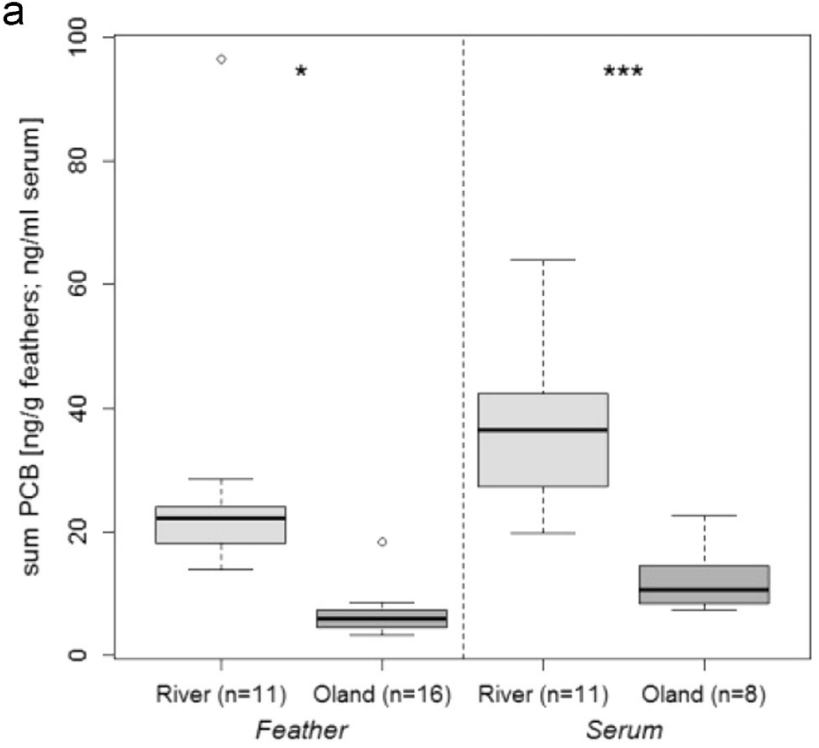

C

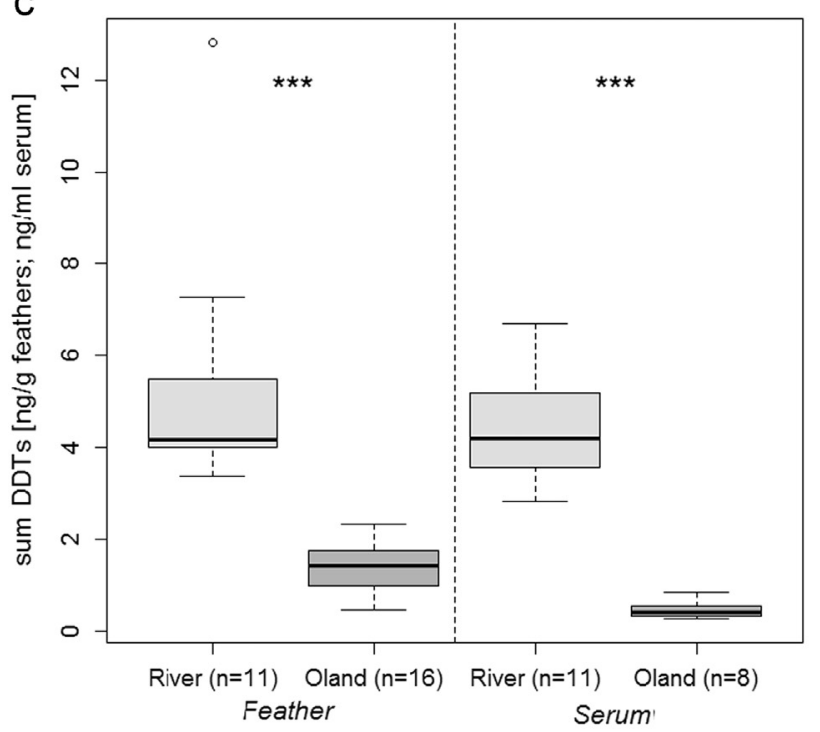

e

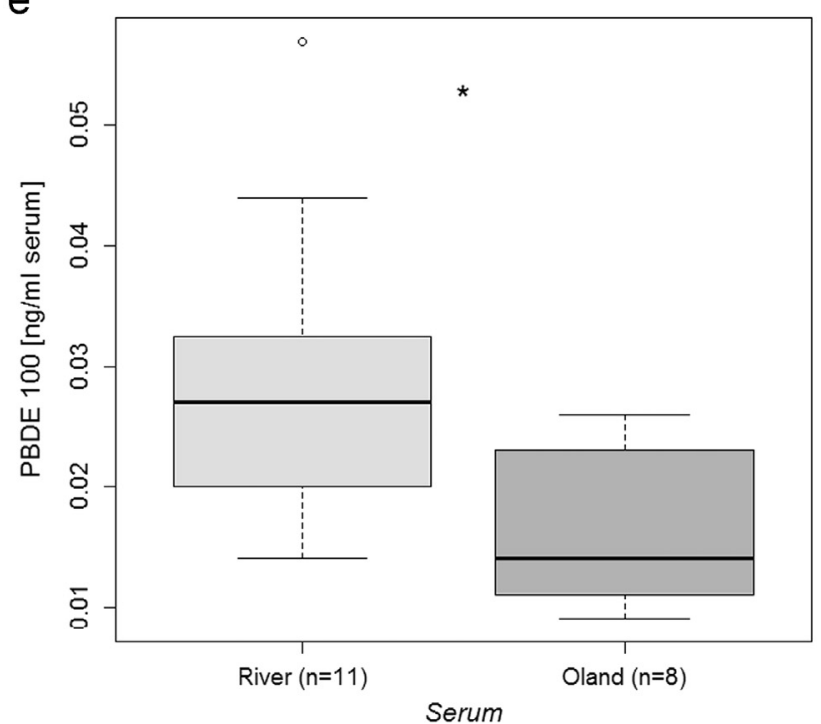

b

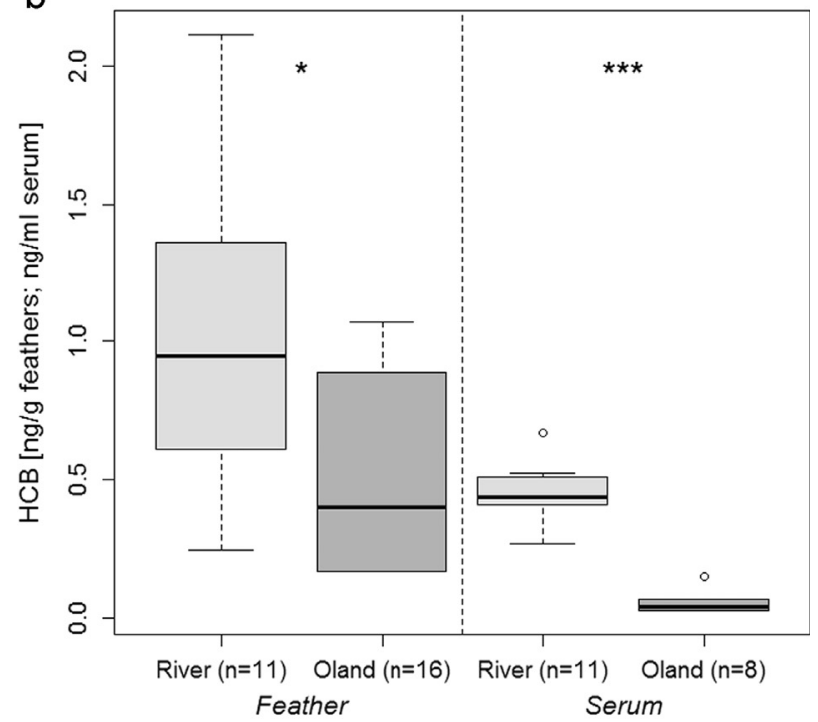

d

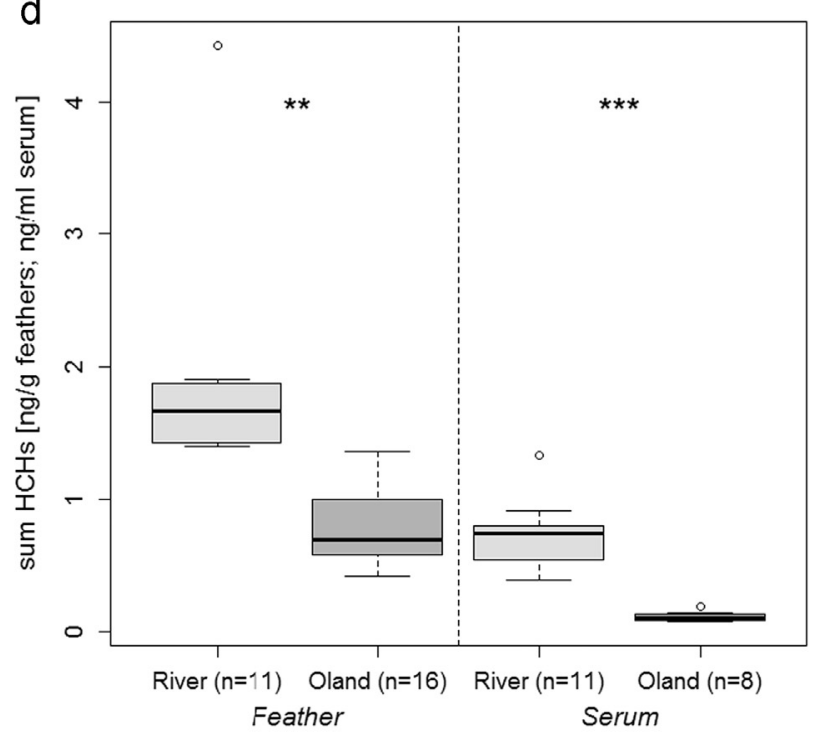

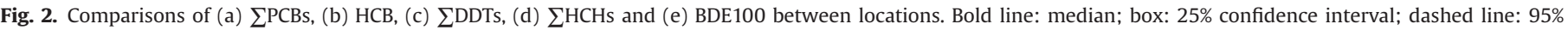
confidence interval; open circles: outlier. ${ }^{*} p<0.05$; ${ }^{* *} p<0.01$; ${ }^{* * *} p<0.001$. Please note different scales of $y$-axes. 

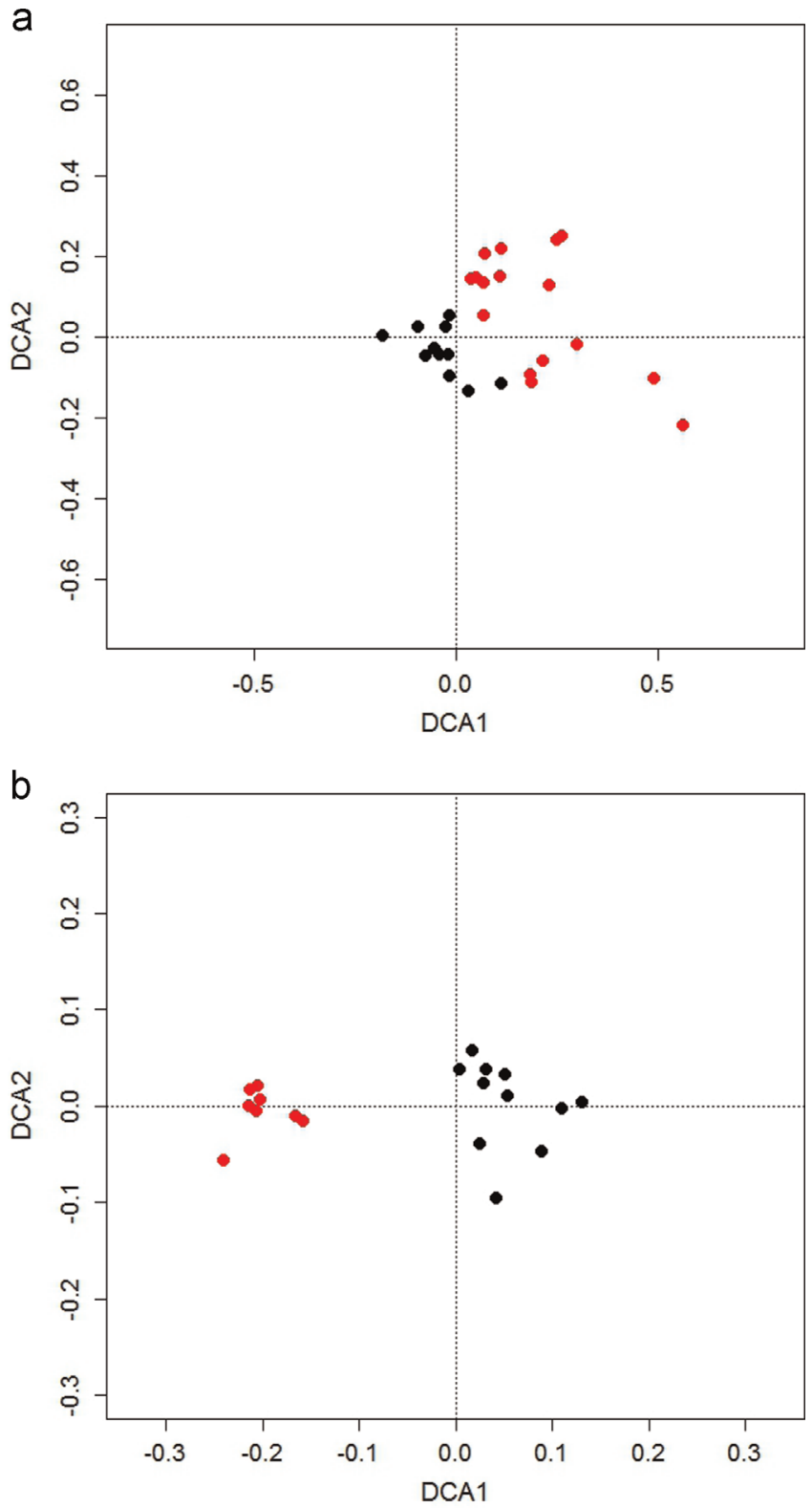

Fig. 3. Detrended component analyses to visualise differences in contaminant composition between the two sites (black: River Elbe; red: Hallig Oland) in (a) feathers and (b) serum. Only contaminants that showed $>50 \%$ LOQ were included (i.e., PCB 118, 138, 153, 170, 180, 187: HCB: p, $p^{\prime}$-DDE: $p, p^{\prime}-\mathrm{DDT}$ : $\alpha$-HCH: and $\beta$ HCH in feathers, and PCB 99, 105, 118, 128, 138, 146, 149, 153, 156, 170, 180, 183, 187: HCB: $p, p^{\prime}-\mathrm{DDE}: \beta-\mathrm{HCH}$; and BDE 100 in serum). (For interpretation of the references to color in this figure legend, the reader is referred to the web version of this article.)

lower than PCB values. Furthermore, the levels of HCB, $\Sigma$ DDTs and $\Sigma \mathrm{HCH}$ sere 2-10 times lower than those for $\sum$ PCBs (Table 1; Fig. 2). Birds from the river location had significantly higher levels of all analysed contaminants compared with birds from the Oland location, both in feathers ( $t$-tests: $\sum$ PCBs: $t=2.97, \mathrm{df}=10.3$, $p<0.05$; HCB: $t=2.5, \mathrm{df}=14.5, p<0.05 ; \sum$ DDTs: $t=4.67, \mathrm{df}=10.6$, $p<0.001 ; \sum \mathrm{HCH}: t=4.07, \mathrm{df}=11.4, p<0.01$; PBDEs: not detectable; Fig. 2) and serum (t-tests; $\sum$ PCBs: $t=5.86, \quad \mathrm{df}=14.1$, $p<0.001$; HCB: $t=10.84, \mathrm{df}=13.8, p<0.001 ; \sum$ DDTs: $t=10.92$, $\mathrm{df}=10.7, p<0.001 ; \sum \mathrm{HCHs}: t=7.49, \mathrm{df}=10.6, p<0.001 ;$ BDE 100 : $t=2.88, \mathrm{df}=15.9, p<0.05$; Fig. 2). $\mathrm{PCB}$ contamination varied strongly among individual oystercatchers.
Table 2

Linear regressions of organic contaminants between feathers and serum. Significant regressions were found in 10 out of 13 cases. Slope $>1$ indicates a stronger accumulation in feathers compared with serum, while a slope $<1$ indicates a stronger accumulation in serum. Confidence intervals include 1 in all cases, indicating that differences in accumulation were non-significant in all cases.

\begin{tabular}{llrllllll}
\hline & Slope & Intercept & $\begin{array}{l}\text { Lower con- } \\
\text { fidence level }\end{array}$ & $\begin{array}{l}\text { Upper con- } \\
\text { fidence level }\end{array}$ & $t$ & $p$ & $\mathrm{R}^{2}$ \\
\hline$\sum$ PCBs & 0.75 & 273.1 & 0.18 & 1.26 & 2.65 & $\mathbf{0 . 0 1 6}$ & 0.29 \\
PCB105 & 1.12 & 0.8 & 0.2 & 2.4 & 1.94 & $\mathbf{0 . 0 2 8}$ & 0.22 \\
PCB118 & 0.98 & 240.1 & 0.2 & 1.7 & 2.71 & $\mathbf{0 . 0 1 8}$ & 0.3 \\
PCB128 & 1.2 & -194.9 & 0.45 & 1.92 & 3.29 & $\mathbf{0 . 0 0 8}$ & 0.39 \\
PCB138 & 0.73 & 600.4 & 0.12 & 1.3 & 2.51 & $\mathbf{0 . 0 2 7}$ & 0.27 \\
PCB153 & 0.87 & -833.9 & 0.26 & 1.49 & 2.77 & $\mathbf{0 . 0 1}$ & 0.31 \\
PCB170 & 0.53 & 562.5 & -0.1 & 1.25 & 1.51 & 0.08 & 0.13 \\
PCB180 & 0.79 & 425.6 & 0.15 & 1.41 & 2.49 & $\mathbf{0 . 0 2 2}$ & 0.27 \\
PCB183 & 0.62 & 90.55 & -0.02 & 1.42 & 1.68 & 0.055 & 0.16 \\
PCB187 & 0.82 & -149.4 & 0.19 & 1.43 & 2.57 & $\mathbf{0 . 0 1 8}$ & 0.28 \\
HCB & 2.23 & 203.5 & 0.53 & 3.3 & 2.38 & $\mathbf{0 . 0 0 7}$ & 0.4 \\
DDE & 1.01 & 591.6 & 0.48 & 1.48 & 4.23 & $\mathbf{0 . 0 0 5}$ & 0.51 \\
$\beta$-HCH & 0.31 & 937.02 & -0.72 & 2.18 & 0.42 & 0.17 & 0.01 \\
\hline
\end{tabular}

Both locations also differed significantly with respect to the compositions of contaminants both in feathers (DECORANA: $\mathrm{DCA} 1=0.7$, DCA2 $=0.72, R^{2}=0.75, p<0.001$; Fig. $3 \mathrm{a}$ ) and in serum (DECORANA: DCA1 $=-0.98$, DCA2 $=-0.22, R^{2}=0.89, p<0.001$; Fig. 3b), indicating major differences in contaminant loads between the two sites. The difference between the sites was more pronounced in serum than in feathers.

Most tested compounds showed significant regressions between feathers and blood, except for CB170, CB183 and $\beta-\mathrm{HCH}$ (Table 2). There was no indication that any compound tended to accumulate more in either tissue (confidence intervals included 1 in all cases), suggesting that the accumulation of contaminants was similar in feathers and serum.

\subsection{Profiles}

It was only possible to establish a profile of different congeners for PCBs, because most PBDE congeners were $<$ LOQ (see above). The PCB congeners 153, 138, 180 and 187 comprised by far the highest proportion of total PCBs in both locations and tissues (Table 1; Fig. 4). However, there were clear differences between the tissues in terms of most of the PCB congeners that accounted for relatively low proportions of the total PCBs. Less-chlorinated PCBs accounted for relatively higher proportions in serum from both locations, but were mostly < LOQ in feathers. PCB 146 was

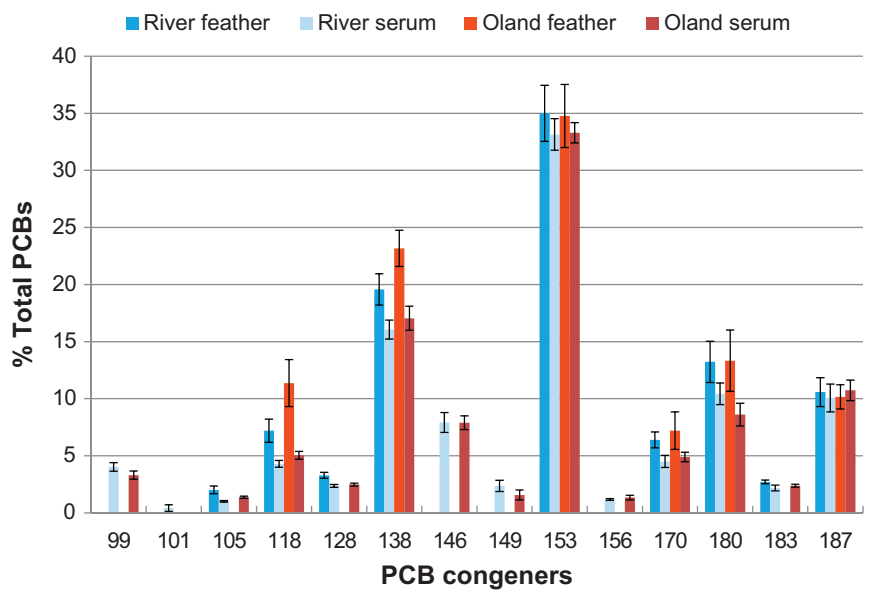

Fig. 4. Contribution of different $\mathrm{PCB}$ congeners to total $\mathrm{PCB}$ in feathers and serum in the River Elbe and Oland locations. 


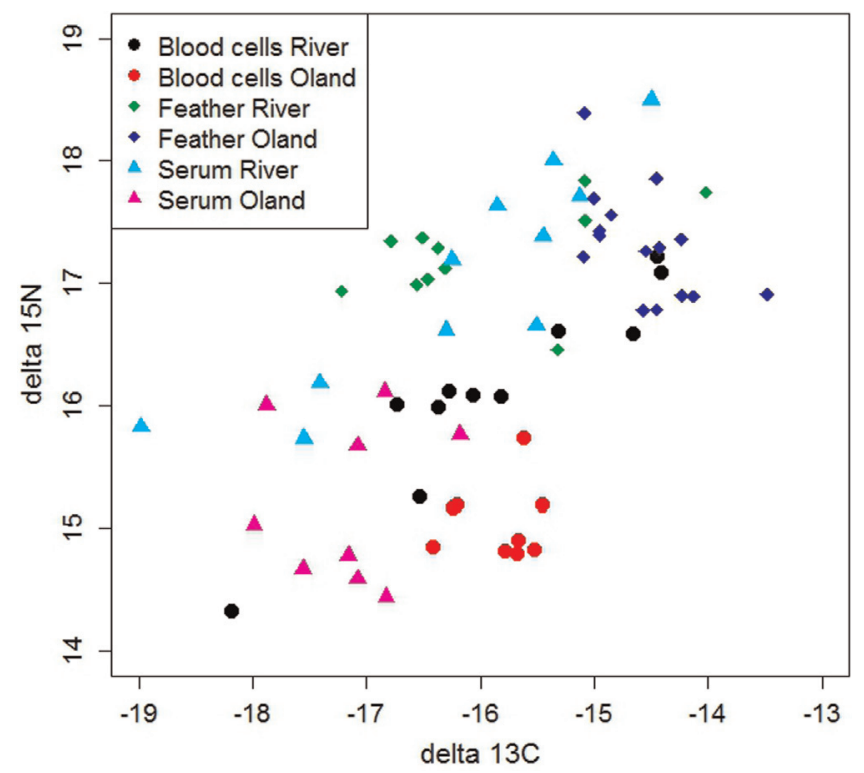

Fig. 5. $\delta^{13} \mathrm{C}$ and $\delta^{15} \mathrm{~N}$ values for feathers (diamonds), serum (triangle) and clotted cells (circles) from birds from the River Elbe and Oland sites.

present at comparably high proportions in serum in both locations, but was undetectable in feathers (Table 1). In general, it was possible to detect most of the tested compounds in serum, but these were often $<$ LOQ in feathers.

\subsection{Differences in stable isotopes between tissues and locations}

There were clear differences in $\delta^{13} \mathrm{C}$ and $\delta^{15} \mathrm{~N}$ values between the two locations (Fig. 5). Individual values of levels in red blood cells and feathers scattered much stronger for the river site compared with the Oland site. Birds from Oland displayed lower $\delta^{15} \mathrm{~N}$ values in all tested tissues compared with birds from the Elbe estuary. Furthermore, there were clear differences between the three tissue types in birds from Oland, with $\delta^{15} \mathrm{~N}$ values in blood cells and serum being much lower than in feathers. $\delta^{13} \mathrm{C}$ values were higher in feathers than blood cells, and the lowest $\delta^{13} \mathrm{C}$ values were found in serum. In contrast, there were only slight differences among tissue types for birds from the river location, and values of stable isotopes in feathers were very similar to those in serum (Fig. 5). Blood cells displayed lower $\delta^{15} \mathrm{~N}$ values than the other two tissue types. There was a positive correlation between $\delta^{13} \mathrm{C}$ and $\delta^{15} \mathrm{~N}$ in blood cells for the river site (linear model: $t=8.54, \mathrm{df}=9, p<0.001$ ) and serum (linear model: $t=5.6, \mathrm{df}=9$, $p<0.001$ ).

\subsection{Relationships between stable isotopes and contaminants}

There was no significant relationship between levels of any class of contaminants in feathers or serum and $\delta^{13} \mathrm{C}$ or $\delta^{15} \mathrm{~N}$, respectively, except for BDE 100 , which was significantly related to $\delta^{15} \mathrm{~N}$ (Table 3).

\section{Discussion}

\subsection{Contamination of the eastern Wadden Sea reflected by oystercatchers}

Oystercatchers feed on a variety of benthic organisms (Hulscher, 1996; Schwemmer et al., 2012) and thus belong among the higher trophic levels of the food web in the Wadden Sea. Piscivorous seabirds such as terns are the top-predators in this ecosystem and have been shown to exhibit higher levels of contaminants than benthivorous birds such as oystercatchers (Becker and Muñoz Cifuentes, 2004; Becker and Dittmann, 2009). Nevertheless, the filter-feeding prey organisms that make up a high proportion of the diet of oystercatchers provide a good reflection of the contaminant load of the ecosystem.

The results of the present study demonstrated significant differences in both the levels and composition of contaminants in oystercatchers between a location influenced by one of Europe's largest river systems and a non-riverine site. Currents within the North Sea transport riverine water from the Elbe in a north-westerly direction (BSH, 2014), and thus away from the sampled nonriverine site, supporting the idea that river discharge may be responsible for the significant differences between the two locations. Although PCB pollution has fallen recently (Bakker et al., 2009), these contaminants persist in organisms at higher trophic levels. Similar differences in contaminant levels between sites close to the River Elbe and non-riverine sites were found in egg shells of oystercatchers and piscivorous common terns (Sterna hirundo) (Beyerbach et al., 1993; Becker and Muñoz Cifuentes, 2004; Becker and Dittmann, 2009). Our data show that blood and feathers can also be used to demonstrate regional differences in organic contaminant loads in top predators on a small spatial scale, as previously shown for heavy metal contamination (Thompson and Dowding, 1999).

In general, levels of all PCB congeners were higher in serum than in feathers; indeed several compounds were undetectable in feathers but present at least at low levels in serum. However, the overall levels of all compounds, both in serum and feathers, were significantly lower compared with the levels in egg shells of oystercatchers and common terns from the Wadden Sea (Becker and Muñoz Cifuentes, 2004; Becker and Dittmann, 2009) and riverine

Table 3

Linear regressions between contaminant levels (sum of all substance classes) in feathers/serum and $\delta 13 \mathrm{C} / \delta 15 \mathrm{~N}$, respectively.

\begin{tabular}{|c|c|c|c|c|c|c|c|c|c|c|}
\hline & \multicolumn{5}{|l|}{$\delta 13 C$} & \multicolumn{5}{|l|}{$\delta 15 N$} \\
\hline & Slope & Intercept & $t$ & $p$ & $R^{2}$ & Slope & Intercept & $t$ & $p$ & $R^{2}$ \\
\hline$\sum \mathrm{PCB}(\mathrm{F})$ & -2946 & $-28,188$ & -0.73 & 0.302 & 0.02 & 302.1 & $11,802.4$ & 0.04 & 0.988 & $<0.01$ \\
\hline$\sum \mathrm{PCB}(\mathrm{S})$ & 921.3 & $39,942.5$ & 0.38 & 0.634 & $<0.01$ & 2887 & $-22,082$ & 0.96 & 0.238 & 0.03 \\
\hline$\sum \mathrm{HCH}(\mathrm{F})$ & -74.8 & 172.9 & -0.45 & 0.505 & 0.01 & -58.2 & 2321.73 & -0.2 & 0.827 & $<0.01$ \\
\hline$\sum \mathrm{HCH}(\mathrm{S})$ & 71.3 & 1602.3 & 1.61 & 0.095 & 0.04 & 94.2 & -1109.2 & 1.65 & 0.073 & 0.09 \\
\hline$\sum \mathrm{HCB}(\mathrm{F})$ & 36.1 & 1314.3 & 0.27 & 0.871 & $<0.01$ & -64.6 & 1862.2 & -0.27 & 0.76 & $<0.01$ \\
\hline$\sum \mathrm{HCB}(\mathrm{S})$ & -9.3 & 95.2 & -0.45 & 0.673 & $<0.01$ & 55.8 & 12.1 & 0.45 & 0.566 & $<0.01$ \\
\hline$\sum$ DDT (F) & -134.8 & 1269.2 & -0.27 & 0.656 & $<0.01$ & 140 & 945.7 & 0.16 & 0.886 & $<0.01$ \\
\hline$\sum \mathrm{DDT}(\mathrm{S})$ & 102.7 & 4146.2 & 0.49 & 0.586 & $<0.01$ & 223.9 & -1186.1 & 0.83 & 0.341 & $<0.01$ \\
\hline BDE $100(\mathrm{~F})$ & nt & nt & nt & nt & nt & nt & nt & nt & nt & nt \\
\hline BDE $100(\mathrm{~S})$ & 2.72 & 68.2 & 1.16 & 0.182 & 0.06 & 5.4 & -64.3 & 2.58 & 0.032 & 0.27 \\
\hline
\end{tabular}

F - feathers; S - serum; nt - not tested. 
sites on the German mainland (Exo et al., 1998). Levels of all contaminants in feathers (except PBDEs, which were significantly lower) were within the range of values reported for a set of terrestrial and aquatic bird species from Belgium (Jaspers et al., 2007). Previous studies have demonstrated that contaminant levels may differ strongly between different bird species and tissue types, with feathers having relatively low levels of contamination (Jaspers et al., 2006, 2007; Voorspoels et al., 2006).

One aim of this study was to elucidate the level of pollution by PBDEs, which are not currently included in the monitoring schemes in the Wadden Sea and which have not yet been adopted as an Ecological Quality Objective (Dittmann et al., 2011). Our results indicated that PBDEs did not represent a problem in the food chain of the German North Sea, given that neither birds from the non-riverine nor the riverine site showed significant amounts. The only congener found at > LOQ was BDE 100 in serum, though levels of this congener were low compared with levels in aquatic and terrestrial bird species from elsewhere (Voorspoels et al., 2006; Jaspers et al., 2006, 2007; Crosse et al., 2012).

\section{2. $P C B$ profiles and differences in contaminant loads between} tissues

There were clear differences in $\mathrm{PCB}$ profiles between the tissues, with less-chlorinated PCBs accounting for relatively higher proportions in serum from birds in both locations. This is in contrast with earlier studies that showed that feathers had higher proportions of less-persistent compounds than internal organs (Dauwe et al., 2004; Jaspers et al., 2007). There might be higher levels in serum in contrast to feathers or internal organs because the liver had no opportunity to metabolise the compounds in serum. Levels of PCB congeners may also differ between feathers and serum because of external contamination of feathers, or contamination from the uropygial gland (e.g., Dauwe et al., 2002, 2004). However, these issues are beyond the scope of the current study.

Contaminant levels in feathers reflect the levels and composition of congeners in blood during the period of feather formation, which might differ from the composition in the blood during the period of blood sampling. Oystercatchers moult most of their feathers after the breeding period (Bauer et al., 2005). Although oystercatchers are comparatively resident birds (Hulscher et al., 1996), some individuals might have left the breeding areas to moult and overwinter at different sites, which could contribute to the differences in contaminant levels between feathers and serum. However, this is only likely to be relevant in some individuals, given that our data showed significant relationships between the levels of most PCB congeners in feathers and serum. Furthermore, no compound accumulated significantly more in one tissue than another, suggesting that feathers were moulted in the breeding area, and that only the less-persistent compounds were not transferred into feather tissues.

The dietary spectrum of oystercatchers from the Wadden Sea is relatively small (Schwemmer et al., 2012) compared with other marine bird species such as gulls (Kubetzki and Garthe, 2003), and levels of contaminants are thus less likely to differ between different time periods. This would further explain the high correlation between serum and feather levels.

\subsection{Differences in stable isotopes between tissues and sites}

Persistent contaminants accumulate in the higher trophic levels of the food chain. We therefore hypothesised that contaminant levels would be higher with increasing values of $\delta^{15} \mathrm{~N}$; furthermore, we hypothesised higher contaminant levels with increasing values of $\delta^{13} \mathrm{C}$ as those would indicate a higher degree of foraging in the potentially more contaminated marine environment (Fry, 2006; Inger and Bearhop, 2008; Ceia et al., 2014). However, we found no indication of such a relationship in either feathers or blood. Jaspers et al. (2007) described the same situation in feather and muscle tissues in a set of terrestrial and aquatic bird species from elsewhere. The most likely explanation for the lack of a relationship between contaminant levels and $\delta^{15} \mathrm{~N}$ is that the diets of individual oystercatchers were too similar to promote strong differences in nitrogen values. In fact, oystercatchers may specialise on a particular diet in a given region (Bunskoeke et al., 1996). Sample sizes were also relatively small and the apparent absence of a link between stable isotope values and contaminant levels should thus be regarded with care.

High $\delta^{15} \mathrm{~N}$ values in coastal birds such as oystercatchers indicate that they feed on prey originating from higher trophic levels, while low $\delta^{13} \mathrm{C}$ values indicate prey of terrestrial origin (Inger and Bearhop, 2008; Ceia et al., 2014). We found higher $\delta^{15} \mathrm{~N}$ values and lower $\delta^{13} \mathrm{C}$ in feathers, compared with serum and blood cells, at the Oland site. We also found lower $\delta^{13} \mathrm{C}$ values in blood at the Elbe site compared with Oland. Isotope ratios in feathers reflect the diet during the period of feather growth, whereas isotope ratios in blood reflect the diet several days before blood sampling (e.g., Evans Ogden et al., 2004). We therefore conclude that oystercatchers from Oland fed more on terrestrial prey with a lower trophic origin during the breeding period (i.e., period of blood sampling) compared with the period of feather growth and compared with birds from the Elbe location. Differences in $\delta^{13} \mathrm{C}$ between the two sites may be associated with differences in primary producers (such as phytoplankton). However, there are some indications that the diets of the oystercatchers differed between the two sites; Kolze (2014) found that oystercatchers from Oland consumed a relatively high proportion of terrestrial prey items (i.e., mostly insects) during the breeding period, which they collected on pastures within the breeding sites. In contrast, oystercatchers from other sites on the German Wadden Sea coast are known to feed on an almost exclusively marine diet (Schwemmer et al., 2012; Schwemmer et al., 2014). This difference is clearly reflected in the terrestrial signatures of serum from birds from the Oland site, compared with individuals from the river mouth.

The high $\delta^{15} \mathrm{~N}$ and $\delta^{13} \mathrm{C}$ values in feathers from the Oland site indicate that the individuals have left the pastures during feather formation and are consuming a more marine diet. The reasons for the stronger terrestrial component in the diet of birds breeding on a Hallig, an island in the centre of the Wadden Sea, are currently unknown. However, there are some indications that the marine prey base around the colony on Oland is currently insufficient to sustain a high number of chicks, and the adults therefore supplement their diet with terrestrial prey (Kolze, 2014; own unpublished data).

The greater use of terrestrial prey in individuals from Oland may explain the lower levels of contamination at this site, because the birds make less use of the potentially more-contaminated marine diet. However, we found no relationship between contaminant levels and $\delta^{13} \mathrm{C}$, suggesting that contaminant loads are independent of the degree of terrestrial feeding. It is also possible that the overall levels of contamination were too low to show proper relationships between stable isotope values and contaminants.

The stable isotope signatures of birds breeding at the riverine site indicate an intermediate nutrition. However, the relatively high variance may reflect strong individual diet specialisation.

\section{Conclusions}

In conclusion, our results suggest that the outflow of one of Europe's largest river systems still shows significant levels of 
contamination that accumulate in the tissues of a predator at the top end of the marine food chain. Although levels of PCBs and DDT are generally much lower than in the past (Becker and Muñoz Cifuentes, 2004; Becker and Dittmann, 2009), values increased again in the short-term from 2008 to 2011, indicating that it might be difficult to meet Ecological Quality Objectives (Dittmann et al., 2011). Trends in contaminant levels in benthivores such as the oystercatcher should thus continue to be monitored within the established schemes. Although PBDEs were not detected in significant amounts in the current study, it might be advisable to include these compounds in the monitoring process.

\section{Acknowledgements}

H. Seibel assisted in blood and feather sampling in the field. B. Egge and S. Müller helped to prepare the samples for analyses. A. and F. Kühn allowed access to the breeding sites on their private land on Hallig Oland. The Nationalpark Administration gave permission to enter the protection zone at the River Elbe and provided financial support for analyses of samples. A. Covaci acknowledges financial support from the Flanders Funds for Scientific Research (FWO) and the University of Antwerp (UA). K. Das and G. Lepoint are F.R.S.-FNRS Research Associates. We thank S. Furness for correcting the English. The authors declare that they have no conflict of interest.

\section{References}

Ahrens, L., Siebert, U., Ebinghaus, R., 2009. Total body burden and tissue distribution of polyfluorinated compounds in harbor seals (Phoca vitulina) from the German Bight. Mar. Pollut. Bull. 58, 520-525.

Bakker J., Lüerßen G., Marencic H., Jung K., 2009. Hazardous Substances. Thematic Report No. 5.1. In: Marencic, H and Vlas, J de (Eds.), 2009. Quality Status Report 2009. Wadden Sea Ecosystem No. 25. Common Wadden Sea Secretariat, Trilateral Monitoring and Assessment Group, Wilhelmshaven, Germany. 〈http:// www.waddensea-secretariat.org/management/publications/the-wadden-seaquality-status-report-2009). (accessed 30.11.13).

Bates D., Maechler M., 2009. Ime4: linear mixed-eVects models using S4 classes. 〈http://cran.r-project.org/web/packages/lme4/index.html〉.

Bauer, G.-H., Bezzel, E., Fiedler, W., 2005. Das Kompendium der Vögel Mitteleuropas - Nonpasseriformes - Nichtsperlingsvögel, second ed. AULA-Verlag, Wiebelsheim.

Becker, P.H., Heidmann, W.A., Büthe, A., Frank, D., Koepff, C., 1992. Umweltchemikalien in Eiern von Brutvögeln der deutschen Nordseeküste: Trends 1981 1990. J. Ornithol. 133, 109-124.

Becker P.H., Dittmann T., 2009. Contaminants in Bird Eggs. Thematic Report No. 5.2 In: Marencic, $\mathrm{H}$ and Vlas, J de (Eds.), 2009. Quality Status Report 2009. WaddenSea Ecosystem No. 25. Common Wadden Sea Secretariat, Trilateral Monitoring and Assessment Group, Wilhelmshaven, Germany. 〈http://www.wad densea-secretariat.org/management/publications/the-wadden-sea-quality-sta tus-report-2009). (accessed 30.11.13).

Becker P.H., Muñoz Cifuentes J., 2004. Contaminants in Bird Eggs: Recent spatial and temoral trends. Wadden Sea Ecosystem No. 18: 5-25. Common Wadden Sea Secretariat, Trilateral Monitoring and Assessment Group, Wilhelmshaven, Germany. 〈http://www.waddensea-secretariat.org/sites/default/files/down loads/wse-18-cont-eggs-01.03.05.pdf . (accessed 20.08.14).

Beyerbach, M., Becker, P.H., Büthe, A., Denker, E., Heidmann, W.A., Staats de Yanés 1993. Variation von PCB-Gemischen in Eiern und Vögeln des Wattenmeeres. J. Ornithol. 134, 325-334.

Blew J., Günther K., Hälterlein B., Kleefstra R., Laursen K., Scheiffarth G., 2013. Trends of migratory and wintering waterbirds in the Wadden Sea 1987/19882010/2011. WaddenSea Ecosystem No. 31. Common Wadden Sea Secretariat, Joint Monitoring Group of Migratory Birds in the Wadden Sea, Wilhelmshaven, Germany. 〈http://www.waddensea-secretariat.org/management/publications/ trends-of-migratory-and-wintering-waterbirds-in-the-wadden-sea-19871988>. (accessed 30.11.13).

Bontempo, L., Deppa, F., Ziller, L., Pedrini, P., Hobson, K.A., Wassenaar, L.I., Camin, F., 2014. Comparison of methods for stable isotope ratios $\left(\delta^{13} \mathrm{C}, \delta^{15} \mathrm{~N}, \delta^{2} \mathrm{H}, \delta^{18} \mathrm{O}\right)$ measurements of feathers. Methods Ecol. Evol. 5, 363-371.

BSH, 2014. Current predictions for the German North Sea. 〈http://www.bsh.de/akt dat/modell/stroemungen/no/noe.htm $\rangle$. (accessed 19.02.14).

Bunskoeke, E.J., Ens, B.J., Hulscher, J.B., de Vlas, S.J., 1996. Why do oystercatchers (Haematopus ostralegus) switch from feeding on baltic tellin (Macoma balthica) to feeding on the ragworm (Nereis diversicolor) during the breeding season? Ardea 84 A, 91-104.

Ceia, F.R., Paiva, V.H., Fidalgo, V., Morais, L., Baeta, A., Crisómo, P., Mourato, E., Garthe, S., Marques, J.C., Ramos, J.A., 2014. Annual and seasonal consistency in the feeding ecology of an opportunistic species, the yellow-legged gull Larus michahellis. Mar. Ecol. Prog. Ser. 497, 273-284.

Crosse, J.D., Shore, R.F., Jones, K.C., Pereira, M.G., 2012. Long term trend in PBDE concentrations in gannet (Morus bassanus) eggs from two UK colonies. Environ. Pollut. 161, 93-100.

CWSS, 2008. Nomination of the Dutch-German Wadden Sea as World Heritage Site. Common Wadden Sea Secretariat, Wilhelmshaven, Germany.

Dauwe, T., Bervoets, L., Blust, R., Eens, M., 2002. Tissue levels of lead in experimentally exposed zebra finches (Taeniopygia guttata) with particular attention on the use of feathers as biomonitors. Arch. Environ. Contam. Toxicol. 42, 88-92.

Dauwe, T., Jaspers, V., Covaci, A., Schepens, P., Eens, M., 2004. Feathers as a nondestructive biomonitor for persistent organic pollutants. Environ. Toxicol. Chem. 24, 442-449.

Dittmann T.D., Becker P.H., Bakker J., Bignert A., Nyberg E., Peiera M.G., Pijanowska U., Shore R., Stienen E.W.M., Toft G.O., Marencic H., 2011 The EcoQO on mercury and organohalogens in coastal bird eggs: report on the pilot study 2008-2010. (INBO.R.2011.43). Research Institute for Nature and Forest, Brussel. 〈http:// www.waddensea-secretariat.org/management/publications/the-eco qo-on-mercury-and-organohalogens-in-coastal-bird-eggs $\rangle$. (accessed 30.11.13).

Eulaers, I., Covaci, A., Herzke, D., Eens, M., Sonne, C., Moum, T., Schnug, L., Hanssen, S.A., Johnsen, T.V., Bustnes, J.O., Jaspers, V.L.B., 2011. A first evaluation of the usefulness of feathers of nestling predatory birds for non-destructive biomonitoring of persistent organic pollutants. Environ. Int. 37, 622-630.

Evans Ogden, L.J., Hobson, K.A., Lank, D.B., 2004. Blood isotopic $\left(\delta^{13} \mathrm{C}\right.$ and $\left.\delta^{15} \mathrm{~N}\right)$ turnover and diet-tissue fractionation factors in captive dunlin (Calidris alpina pacifica). Auk 121, 170-177.

Exo, K.-M., Becker, P.H., Sommer, U., 1998. Umweltchemikalien in Eiern von Binnenland- und Wattenmeerbriitern des Austernfischers (Haematopus ostralegus). J. Ornithol. 139, 401-405.

Faraway, J.J., 2006. Extending the Linear Model with R. Generalized Linear, Mixed Effects and Nonparametric Regression Models. Chapman \& Hall, Boca Raton.

Furness, R.W., 1993. Birds as monitors of pollutants. In: Furness, R.W., Greenwood, J. J.D. (Eds.), In Birds as Monitors of Environmental Change. Chapman \& Hall, London, pp. 86-143.

Fry, B., 2006. Stable Isotope Ecology. Springer, New York.

Halpern, B.S., et al., 2008. A global map of human impact on marine ecosystems. Science 319, 948-952.

Hill, M.O., Gauch, H.G., 1980. Detrended correspondence analysis: an improved ordination technique. Vegetatio 42, 47-58.

Hulscher, J.B., 1996. Food and feeding behaviour. In: Goss-Custard, J.D. (Ed.), Oystercatchers - from individuals to populations. Oxford University Press, New York.

Hulscher, J.B., Exo, K.-M., Clark, N.A., 1996. Why do Oystercatchers migrate?. In: Goss-Custard, J.D. (Ed.), Oystercatchers - from Individuals to Populations. Oxford University Press, New York.

Inger, R., Bearhop, S., 2008. Applications of stable isotope analyses to avian ecology. Ibis 150, 447-461.

Jaspers, V.L.B., Covaci, A., Voorspoels, S., Dauwe, T., Eens, M., Schepens, P., 2006. Brominated flame retardants and organochlorine pollutants in aquatic and terrestrial predatory birds of Belgium: levels, patterns, tissue distribution and condition factors. Environ. Pollut. 139, 340-352.

Jaspers, V.L.B., Voorspoels, S., Covaci, A., Lepoint, G., Eens, M., 2007. Evaluation of the usefulness of bird feathers as a non-destructive biomonitoring tool for organic pollutants: a comparative and meta-analytical approach. Environ. Int. 33, 328-337.

Jaspers, V.L.B., Covaci, A., Deleu, P., Neels, H., Eens, M., 2008. Preen oil as the main source of external contamination with organic pollutants onto feathers of the common magpie (Pica pica). Environ. Int. 34, 741-748.

Koffijberg K., Blew J., Eskildsen K., Günther K., Koks B., Laursen K., Rasmussen L.-M., Potel P., Südbeck P., 2003 High tide roosts in the Wadden Sea. Wadden Sea Ecosystem No. 16, Common Wadden Sea Secretariat, Joint Monitoring Group of Migratory Birds in the Wadden Sea, Wilhelmshaven, Germany. 〈http://www. waddensea-secretariat.org $>$, (accessed 20.04.14).

Koffijberg K., Dijksen L., Hälterlein B., Laursen K., Potel P., Südbeck P., 2013. Trends of breeding birds in the Wadden Sea 1991-2009. Common Wadden Sea Secretariat, Joint Monitoring Group of Breeding Birds in the Wadden Sea, Wilhelmshaven, Germany.

Kolze, A.-L., 2014. Nahrung und Biometrie von toten Austernfischerküken der Hallig Oland. University of Kiel (Bachelor thesis).

Kubetzki, U., Garthe, S., 2003. Distribution, diet and habitat selection by four sympatrically breeding gull species in the south-eastern North Sea. Mar. Biol. 143, 199-207.

Laursen K., Blew J., Eskildsen K., Günther K., Hälterlein B., Kleefstra R., Lüerßen G., Potel P., Schrader S., 2010. Migratory Waterbirds in the Wadden Sea 1987-2008. Wadden Sea Ecosystem No.30. Common Wadden Sea Secretariat, Joint Monitoring Group of Migratory Birds in the Wadden Sea, Wilhelmshaven, Germany. 〈http://www.waddensea-secretariat.org/management/publications/migrator y-waterbirds-in-the-wadden-sea-1987-2008-trend-phenology $\rangle$. (accessed 30.11.13). 
Michalik, A., McGill, R.A.R., Furness, R.W., Eggers, T., van Noordwijk, H.J., Quillfeldt, P., 2010. Black and white - does melanin change the bulk carbon and nitrogen isotope values of feathers? Rapid Commun. Mass Spectrom. 24, 875-878.

Montevecchi, W.A., 1993. Birds as indicators of change in marine prey stocks. In: Furness, R.W., Greenwood, J.J.D. (Eds.), Birds as Monitors of Environmental Change. Chapman \& Hall, London, pp. 216-266.

Montevecchi, W.A., Myers, R.A., 1996. Dietary changes of seabirds indicate shift in pelagic food webs. Sarsia 80, 313-322.

Oksanen, J., Minchin, P.R., 1997. Instability of ordination results under changes in input data order: explanations and remedies. J. Veg. Sci. 8, 447-454.

Ponsard, S., Averbuch, P., 1999. Should growing and adult animals fed on the same diet show different $\delta 15 \mathrm{~N}$ values? Rapid Commun. Mass Spectrom. 13 1305-1310.

RDevelopment Core Team, 2013. R: A Language and Environment for Statistical Computing, R Foundation for Statistical Computing, Vienna, Austria. 2013. (accessed 29.09.13).

Schwemmer, H., Schwemmer, P., Ehrich, S., Garthe, S., 2013. Lesser black-backed gulls (Larus fuscus) consuming swimming crabs: an important link in the food web of the southern North Sea. Estuar. Coast. Shelf Sci. 119, 71-78.

Schwemmer, P., Garthe, S., 2011. Spatial and temporal patterns of habitat use by Eurasian oystercatchers (Haematopus ostralegus) in the eastern Wadden Sea revealed using GPS data loggers. Mar. Biol. 158, 541-550.

Schwemmer, P., Güpner, F., Guse, N., Garthe, S., 2012. Nahrungswahl von Vogelarten der deutschen Nordseeküste. Vogelwarte 50, 141-154.
Schwemmer, P., Hälterlein, B., Geiter, O., Corman, V., Günther, K., Garthe, S., 2014. Weather-related winter mortality of Eurasian Oystercatchers (Haematopus ostralegus) in the north-eastern Wadden Sea. Waterbirds 37, 319-330.

Sokal, R.R., Rohlf, F.J., 1981. Biometry. Freeman and Company, New York.

Thompson, D.R., Dowding, J.E., 1999. Site-specific heavy metal concentrations in blood of South Island Pied Oystercatchers (Haematopus ostralegus finschi) from the Auckland Region, New Zealand. Mar. Pollut. Bull. 38, 202-206.

Thompson, D.R., Hamer, K.C., 2000. Stress in seabirds: causes, consequences and diagnostic value. J. Aquat. Ecosyst. Stress Recover. 7, 91-110.

Venables, W.N., Ripley, B.D., 2002. Modern Applied Statistics with S. Springer, New York.

Voorspoels, S., Covaci, A., Maervoet, J., Schepens, P., 2002. Relationship between age and levels of organochlorine contaminants in human serum of a Belgian population. Bull. Environ. Contam. Toxicol. 69, 22-29.

Voorspoels, S., Covaci, A., Lepom, P., VLB, Jaspers, Schepens, P., 2006. Levels and distribution of polybrominated diphenyl ethers in various tissues of birds of prey. Environ. Pollut. 144, 218-227.

WWF, 2000. Gefahren für die menschliche Gesundheit durch hormonell wirksame Zusätze in Kunstroffprodukten - Flammschutzmittel, Weichmacher und Organozinnverbindungen. WWF Deutschland, Frankfurt am Main. Meiners Druck OHG, Bremen. 